\title{
PERBANDINGAN KEMAMPUAN MATHEMATICAL PROBLEM POSING SISWA ANTARA PENDEKATAN OPEN-ENDED DAN PENDEKATAN SAINTIFIK
}

\author{
Harry Dwi Putra', Risma Amelia², Ratna Sariningsih ${ }^{3}$ \\ 1,2,3 IKIP Siliwangi, JI. Terusan Jenderal Sudirman, Cimahi, Indonesia \\ Email: ${ }^{2}$ risma.gembil@gmail.com
}

\begin{abstract}
This study aims to analyze the mathematical problem posing ability of vocational school students between those who use open-ended approach and scientific approach. The research population is vocational school students of grade XI at SMK TI Pembangunan Cimahi City, West Java. The sample was obtained by purposive sampling technique, which is two classes with students' mathematical abilities that do not differ significantly so that two classes are obtained namely $\mathrm{XI}$ RPL-B as an experimental class that uses an open-ended approach and XI TEI-C as a control class that uses a scientific approach. Both classes have mathematical abilities that do not differ significantly through t-tests. The research method uses quasi-experimentation. The instrument is used in the form of a mathematical problem posing ability test which amounts to five points of description in quadratic equation material. The data analysis technique uses a statistic independent sample t-test test against the results of pretest and posttest data of experimental classes and control classes through normality tests and Mann-Whitney nonparametric tests. The results showed that students' mathematical problem posing ability uses an open-ended approach better than using a scientific approach. An open-ended approach gives students more opportunities to explore new problem-solving activities or create questions based on available information, making students' answers more diverse.
\end{abstract}

Keywords: Mathematical problem posing ability, open-ended approach, scientific approach

\begin{abstract}
ABSTRAK
Penelitian ini bertujuan untuk menganalisis kemampuan mathematical problem posing siswa SMK antara yang menggunakan pendekatan open-ended dan pendekatan saintifik. Populasi penelitian adalah siswa SMK kelas XI di SMK TI Pembangunan Kota Cimahi, Jawa Barat. Sampel diperoleh dengan teknik purposive sampling, yaitu dua kelas dengan kemampuan matematis siswa yang tidak berbeda secara signifikan, sehingga diperoleh dua kelas yaitu XI RPL-B sebagai kelas eksperimen yang menggunakan pendekatan open-ended dan XI TEI-C sebagai kelas kontrol yang menggunakan pendekatan saintifik. Kedua kelas memiliki kemampuan matematis yang tidak berbeda secara signifikan melalui uji-t. Metode penelitian menggunakan kuasi eksperimen. Instrumen yang digunakan berupa tes kemampuan mathematical problem posing yang berjumlah lima butir soal uraian pada materi persamaan kuadrat. Teknik analisis data menggunakan uji statistic independent sample t-test terhadap hasil data pretest dan posttest kelas eksperimen dan kelas kontrol melalui uji normalitas, dan uji nonparametrik Mann-Whitney. Hasil penelitian menunjukkan bahwa kemampuan mathematical problem posing siswa menggunakan pendekatan open-ended lebih baik daripada menggunakan pendekatan saintifik. Pendekatan open-ended memberikan siswa kesempatan yang lebih banyak dalam mengeksplorasi aktivitas menyusun masalah baru atau membuat pertanyaan berdasarkan informasi yang tersedia, sehingga jawaban siswa menjadi lebih beraneka ragam.
\end{abstract}

Kata kunci: Kemampuan mathematical problem posing, pendekatan open-ended, pendekatan saintifik

Dikirim: 8 November 2019; Diterima: 25 Februari 2020; Dipublikasikan: 30 Maret 2021

Cara sitasi: Putra, H. D., Amelia, R., \& Sariningsih, R. (2021). Perbandingan kemampuan mathematical problem posing siswa antara pendekatan open-ended dan pendekatan saintifik. Teorema: Teori dan Riset Matematika, 6 (1), 69-81. Doi: http://dx.doi.org/10.25157/teorema.v6i1.2932 


\section{PENDAHULUAN}

Kurikulum 2013 menggunakan pendekatan saintifik yang berorientasi pada siswa dalam menemukan konsep dan prinsip dari materi yang dipelajari. Sinambela (2013) mengemukakan bahwa dengan diterapkannya pembelajaran diharapkan seimbang dan meningkatnya kemampuan (softskill), memiliki kecakapan, dan pengetahuan (hardskill) dari siswa yang meliputi bagian kompetensi sikap, pengetahuan dan keterampilan. Menurut Hosnan (2016) bahwa mengimplementasikan kurikulum 2013 dengan pembelajaran yang dirancang dengan sedemikian rupa dapat membuat siswa aktif mengkontruksi konsep sesuai tahapan pendekatan saintifik.

Pada kenyataannya, ketika observasi di salah satu SMK di Cimahi Jawa Barat siswa mengalami kesulitan dalam menemukan konsep, sehingga menjadi kendala dalam menyelesaikan masalah matematika. Hambatan lainnya, tidak meratanya kemampuan siswa dalam memahami konsep. Pada saat diberikan soal non-rutin, sebagian siswa mengalami kesulitan dalam menyelesaikan. Mereka tidak dapat memahami soal secara utuh, sehingga tidak mampu mengubah soal cerita ke dalam model matematika. Kemampuan siswa dalam pengajuan masalah matematik masih menjadi kendala. Hal ini menunjukkan kemampuan mathematical problem possing siswa masih rendah.

Iskandar (2014) mengemukakan beberapa hambatan yang dihadapi dalam pembelajaran matematika adalah waktu yang tersedia relatif sedikit untuk melakukan pengembangan dalam pembelajaran, kesulitan dalam membuat soal-soal latihan pada LKS secara baik, beragamnya tingkat kemampuan siswa sehingga terjadi tidak produktifnya pada kelompok tersebut. Berdasarkan hal tersebut perlu diterapkannya pendekatan lain selain pendekatan saintifik untuk meningkatkan kemampuan mathematical problem posing siswa yang dapat melatih siswa untuk terbiasa mengajukan masalah dan dapat memahami soal serta dapat mengeksplore masalah yang diajukan sehingga peneliti menerapkan pendekatan open-ended yang sesuai dengan kriteria tersebut.

Komalasari et al. (2018) dalam penelitiannya mengenai analisis soal kemampuan mathematical problem posing menunjukkan bahwa kategori yang paling sulit atau rendah dengan persentase $11 \%$. Hal tersebut dikarenakan siswa belum mampu membuat soal yang mirip dengan soal sebelumnya yang maknanya sama dan siswa kurang menguasai konsepnya. Pada dasarnya kegiatan mengajukan masalah atau pengajuan masalah atau problem posing tergolong kedalam kegiatan yang mendukung terjadinya pembelajaran student center yang akan memicu siswa agar tidak pasif dalam belajar.

Pua et al. (2017) mengungkapkan bahwa pengajuan masalah dapat menyebabkan siswa bertindak berdasarkan pola pikir atau mental untuk menyelesaikan suatu masalah dan salah satu aktivitas siswa untuk meningkatkan mutu pembelajaran matematika adalah mengembangkan kemampuan siswa dalam membuat soal. Dengan demikian, untuk mendorong siswa aktif dan berlatih dalam menggunakan pikirannya secara logis, sistematis, berpikir kritis dan kreatif maka siswa membutuhkan kemampuan dalam memahami konsep matematika. Salah satu kemampuan yang bisa membentuk pola pikir siswa adalah kemampuan mathematical problem posing atau pengajuan masalah.

Afrilianto (2014) berpedapat bahwa siswa perlu mengembangkan kemampuan mathematical problem posing karena dalam matematika membutuhkan ide-ide kreatif sehingga dapat memunculkan pertanyaan-pertanyaan baru. Problem posing sangat penting dalam melatih siswa menyusun masalah sehingga tumbuh kreativitas saat menyusun pertanyaan-pertanyaan yang akan diajukan (Komalasari et al., 2018). Oleh karena itu kemampuan mathematical problem posing perlu dimiliki dan dikuasai siswa karena bisa atau tidaknya seseorang dalam menyelesaikan masalah tergantung ketika menyusun masalah tersebut. Dengan kemampuan ini siswa diharapkan untuk mengajukan masalah berdasarkan informasi pada saat kegiatan pembelajaran atau kegiatan lainnya. Putra et al. (2017) memandang problem posing sebagai suatu kegiatan yang dapat memberikan pengalaman bagi siswa untuk mencari dan membuat masalah matematika. Jadi, 
pengajuan masalah merupakan aktivitas yang diawali dengan merancang dan menyusun masalah dan menyelesaikannya.

Elerton dan Clarkson (Afriansyah, 2017) mengemukakan bahwa problem posing atau pengajuan masalah penting dimiliki siswa, karena aktivitas ini dapat mengembangkan kemampuan mereka dalam berimajinasi secara kreatif ketika menyusun pertanyaan baru, memformulasikan masalah, dan menyelesaikan masalah. Oleh karena itu, siswa perlu memiliki kemampuan dalam menyelesaikan masalah dan juga kemampuan mengajukan masalah. Kemampuan mathematical problem posing dapat meningkatkan kemampuan matematis siswa, sebab dalam menyusun soal, siswa perlu membaca dan memahami suatu informasi yang diberikan, kemudian disusun kembali dalam bentuk pertanyaan baru.

Adapun indikator kemampuan mathematical problem posing (Putra et al., 2017) yaitu: (1) menyusun masalah baru berdasarkan materi persamaan kuadrat; (2) menyatakan masalah yang serupa, namun memiliki makna yang sama pada materi persamaan kuadrat; (3) mengajukan pertanyaan dari serangkaian informasi materi persamaan kuadrat yang semi terstruktur; (4) merinci soal mengenai materi persamaan kuadrat ke dalam pertanyaan bagiannya; dan (5) membuat pertanyaan sebelum, selama, dan sesudah menyelesaikan masalah materi persamaan kuadrat.

Upaya dalam meningkatkan prestasi belajar matematika siswa dan pentingnya kemampuan pengajuan masalah melalui penerapan pembelajaran yang inovatif. Salah satu pembelajaran inovatif tersebut adalah pendekatan open-ended. Fatah et al. (2016) dan Erickson (2020) mengartikan pendekatan open-ended dengan pemberian jenis tugas yang memiliki beberapa cara penyelesaian yang benar atau memiliki beberapa kemungkinan jawaban. Zakiah (2016) mengungkapkan bahwa keberagaman cara penyelesaian atau jawaban tersebut memberikan kesempatan bagi siswa untuk menginvestigasi berbagai strategi dan cara yang diyakininya sesuai dengan kemampuan yang dimilikinya untuk mengelaborasi permasalahan.

Sakti et al. (2017) menyebutkan bahwa pendekatan open-ended merupakan pendekatan yang menyajikan suatu masalah terbuka yang dapat mengembangkan pola pikir siswa. Melihat indikator kemampuan mathematical problem posing siswa sesuai dengan kriteria pendekatan openended dimana siswa diberikan kesempatan untuk menuangkan ide atau gagasannya, sehingga dengan pendekatan open-ended kemampuan mathematical problem posing siswa dapat terlatih.

Upaya dalam meningkatkan kemampuan mathematical problem posing siswa, salah satu alternatif solusinya menggunakan pendekatan pembelajaran yang dapat mengakomodir siswa dalam membuat pertanyaan dan menyelesaikannya. Salah satu pendekatan pembelajaran tersebut adalah open-ended. Menurut Sudiarta (2005) bahwa pendekatan open-ended dapat menambah wawasan siswa mengenai materi atau konsep matematika yang dipelajari. Siswa tidak hanya menemukan solusi dari masalah, tetapi juga memberikan argumen atas solusi tersebut.

Pendekatan open-ended melatih siswa memahami masalah dan kreatif dalam mengeksplor masalah yang diajukan, sehingga mereka menjadi lebih aktif dan kreatif. Fokus utama pendekatan open-ended yaitu siswa dapat mengeksplorasi strategi permasalahan dengan berbagai cara. Hal ini sejalan dengan indikator mathematical problem posing sehingga pendekatan open-ended dapat meningkatkan kemampuan mathematical problem posing siswa.

Adapun langkah-langkah pendekatan open-ended (Suherman, 2011) yaitu: (1) memberikan masalah terbuka; (2) pengorganisasian; (3) memperhatikan dan mencatat respon siswa; (4) membimbing dan mengarahkan; dan (5) kesimpulan. Berdasarkan langkah-langkah yang diterapkan dalam pendekatan open-ended hal ini dapat mengembangkan kemampuan mathematical problem posing siswa.

Pada tahapan memberikan masalah terbuka pada pendekatan open-ended memberikan kesempatan kepada siswa untuk menyusun masalah baru, mengajukan pertanyaan dan merinci soal berdasarkan materi yang diajarkan sesuai dengan indikator yang ada pada kemampuan mathematical problem posing. Hal ini didukung oleh Melianingsih \& Sugiman (2015) yang menyebutkan bahwa pendekatan open-ended dapat memberikan kesempatan yang seluas-luasnya 
kepada siswa agar aktivitas dan pemikiran matematis siswa berkembang sehingga dapat memberikan keleluasaan kepada siswa dalam mengembangkan kemampuan mathematical problem posing-nya.

Berdasarkan uraian di atas, untuk menganalisis efektivitas antara pendekatan open-ended dan pendekatan saintifik terhadap kemampuan mathematical problem posing perlu dilakukan eksperimen pada siswa. Pendekatan open-ended dianggap dapat melatih kemampuan mathematical problem posing. Pendekatan saintifik merupakan pendekatan yang diterapkan dalam kurikulum 2013.

\section{METODE PENELITIAN}

Metode yang digunakan dalam penelitian ini adalah metode kuasi-eksperimen. Teknik pengambilan sampel menggunakan purposive sampling dengan pertimbangan bahwa kemampuan awal siswa dari kedua kelas tersebut sama. Dalam penelitian ini terdapat dua jenis variabel yaitu variabel bebas dan variabel terikat. Variabel bebas dalam penelitian ini adalah pendekatan openended dan pendekatan saintifik, sedangkan variabel terikatnya adalah kemampuan mathematical problem posing. Desain yang digunakan adalah sebagai berikut.

Keterangan:

$$
-\frac{0}{0}-\frac{X_{1}}{C} \frac{0}{0}-
$$

$0 \quad$ : Pretest $=$ Posttest kemampuan mathematical problem posing

$---\cdot$ : Pengambilan sampel tidak secara acak

$\mathrm{X}_{1} \quad$ : Pembelajaran dengan pendekatan open-ended

C : Pembelajaran dengan pendekatan saintifik

Populasi dalam penelitian ini adalah seluruh siswa kelas XI SMK TI Pembangunan Cimahi. Teknik pengambilan sampel menggunakan purposive sampling yaitu dua kelas yang memiliki kemampuan matematis yang tidak berbeda secara signitifkan. Diperoleh sampel siswa kelas XI RPL-B sebagai kelas eksperimen dengan pembelajaran menggunakan pendekatan open-ended dan $\mathrm{XI}$ TEI-C sebagai kelas kontrol dengan pembelajaran menggunakan pendekatan saintifik. Kedua kelas merupakan kelas yang homogen yaitu memiliki rata-rata kemampuan awal siswa yang sama. Instrumen yang digunakan dalam penelitian ini yaitu instrumen tes kemampuan mathematical problem posing yang berjumlah lima butir soal uraian pada materi persamaan kuadrat.

Indikator kemampuan mathematical problem possing diadopsi dari Putra (2017) dan Putra et al. (2020) yaitu: (1) menyusun masalah baru berdasarkan materi; (2) menyatakan masalah yang mirip namun memiliki makna sama yang sesuai dengan materi; (3) mengajukan pertanyaan dari serangkaian informasi matematis yang semi terstruktur; (4) merinci soal mengenai materi ke dalam pertanyaan bagiannya; (5) membuat pertanyaan sebelum, selama, dan sesudah menyelesaikan masalah.

Tes kemampuan mathematical problem posing yang telah disusun berdasarkan kelima indikator tersebut, selanjutnya dilakukan validasi oleh tiga orang ahli yaitu dosen pendidikan matematika untuk melihat kesesuian terhadap konten (isi materi), konstruk (susunan materi), dan empiris (berdasarkan pengalaman). Hasil validasi tes kemampuan mathematical problem posing disajikan pada Tabel 1.

Tabel 1. Rekapitulasi hasil validasi instrumen berdasarkan ahli

\begin{tabular}{clccccc}
\hline No. & Komponen & Ahli I & Ahli 2 & Ahli 3 & Rata-rata & Kriteria \\
\hline 1. & Isi (Konten) & 3,5 & 3 & 3,25 & 3,25 & Valid \\
2. & Konstruk & 3 & 3,25 & 3 & 3,08 & Valid \\
3. & Empiris & 3,25 & 3,25 & 3 & 3,17 & Valid \\
& & Jumlah & & & 9,50 & \\
& & Rata-rata & & & 3,17 & Valid \\
\hline
\end{tabular}


Tabel 1 menampilkan hasil validasi tes kemampuan mathematical problem posing dari tiga dosen pendidikan matematika. Skor yang diberikan ketiga orang ahli tersebut memiliki rata-rata valid, sehingga tes tersebut valid dan dapat digunakan sebagai tes untuk mengukur kemampuan mathematical problem posing siswa.

Selanjutnya, tes yang telah divalidasi oleh tiga orang ahli diuji cobakan pada siswa kelas XII yang telah mempelajari materi persamaan kuadrat untuk mengukur validitas, reliabilitas, daya pembeda, dan indeks kesukarannya. Hasil analisis uji coba tes kemampuan mathematical problem posing ditampilkan pada Tabel 2.

Tabel 2. Rekapitulasi hasil uji coba instrumen

\begin{tabular}{ccccccccc}
\hline Soal & Validitas & Kriteria & Reliabilitas & Kriteria & DP & Kriteria & IK & Kriteria \\
\hline 1 & 0,680 & Sedang & & & 0,325 & Cukup & 0,644 & Sedang \\
2 & 0,857 & Tinggi & & & 0,672 & Baik & 0,597 & Sedang \\
3 & 0,483 & Sedang & 0,799 & Tinggi & 0,444 & Baik & 0,659 & Sedang \\
4 & 0,739 & Sedang & & & 0,270 & Cukup & 0,242 & Sukar \\
5 & 0,604 & Sedang & & & 0,255 & Cukup & 0,505 & Sedang \\
\hline
\end{tabular}

Berdasarkan hasil uji coba tes pada Tabel 2, dapat dinyatakan bahwa tes layak digunakan untuk mengukur kemampuan mathematical problem posing siswa karena nilai validitas berada antara sedang dan tinggi, reliabilitas yang tinggi, daya pembeda pada kriteria cukup dan baik, serta indeks kesukaran pada kriteria sedang dan sukar.

Pengolahan data tes kemampuan mathematical problem posing di kelas eksperimen dan kontrol dilakukan secara kuantitatif menggunakan uji statistik yaitu uji normalitas, uji nonparametrik Mann-Whitney atau independent sample t-test terhadap hasil data pretest dan posttest di kelas eksperimen dan kelas kontrol. Uji statistik ini dimaksudkan untuk menganalisis perbandingan kemampuan mathematical problem posing siswa antara pendekatan open-ended dan pendekatan saintifik.

\section{HASIL DAN PEMBAHASAN}

Penelitian ini dilaksanakan pada dua kelas dengan perlakukan yang berbeda, yaitu kelas eksperimen dengan menggunakan pendekatan open-ended dan kelas kontrol dengan pendekatan saintifik. Teknik pengumpulan data yang dilakukan yaitu melalui tes instrumen kemampuan mathematical problem posing. Tes yang dilakukan yaitu pretest (sebelum penerapan pendekatan) dan posttest (setelah penerapan pendekatan) untuk mengetahui bagaimana kemampuan mathematical problem posing siswa antara yang menggunakan pendekatan open-ended dan pendekatan saintifik sebelum dan sesudah diterapkannya pembelajaran dengan pendekatan yang berbeda tersebut.

Skor pretest siswa di kelas eksperimen dan kontrol diolah dan dianalisis menggunakan bantuan software SPSS versi 16 for Windows dengan taraf signifikansi sebesar $5 \%(0,05)$. Hasil deskripsi skor data pretest kemampuan mathematical problem posing disajikan pada Tabel 3.

Tabel 3. Deskripsi skor pretest kemampuan mathematical problem posing

\begin{tabular}{ccccc}
\hline & Kelas & N & Rata-rata & Std Deviasi \\
\hline \multirow{3}{*}{ Pretest } & Eksperimen & 32 & 8.281 & 5.005 \\
& Kontrol & 32 & 7.438 & 3.068 \\
& SMl & & 50 & \\
\hline
\end{tabular}

Berdasarkan Tabel 3 terlihat bahwa rata-rata kelas eksperimen sebesar 8,281 sedangkan kelas kontrol yaitu 7,438 dengan selisih rata-rata nilai pretest untuk kelas eksperimen dan kelas kontrol sebesar 0,843 . Selisih ini menunjukkan nilai rata-rata pretest dari kedua kelas memiliki selisih yang tidak terlalu jauh atau hampir sama. Untuk menganalisis selisih skor pretest tersebut berbeda atau tidak secara signifikan, selanjutnya dilakukan uji perbedaan dua rata-rata menggunakan uji-t dua pihak. Untuk melakukan uji-t dua pihak melalui uji normalitas terlebih dahulu. 
Uji normalitas bertujuan untuk data tes kedua kelas berdistribusi normal atau tidak. Uji statistik menggunakan uji Shapiro-wilk karena jumlah sampel kurang dari 100. Taraf signifikansi sebesar 0,05. Rumusan hipotesis statistik uji normalitas sebagai berikut:

$\mathrm{H}_{0}$ : Data tes kedua kelas berdistribusi normal.

$\mathrm{H}_{\mathrm{a}}$ : Data tes kedua kelas tidak berdistribusi normal.

Kriteria pengujian:

Jika nilai Sig. $\geq 0,05$, maka data kedua kelas berdistribusi normal.

Jika nilai Sig. $<0,05$, maka data kedua kelas tidak berdistribusi normal.

Hasil uji normalitas data pretest kemampuan mathematical problem posing siswa dari kedua kelas ditampilkan pada Tabel 4.

Tabel 4. Uji normalitas data pretest kemampuan mathematical problem posing

\begin{tabular}{llccc}
\hline & \multirow{2}{*}{ Kelas } & \multicolumn{3}{c}{ Shapiro-Wilk } \\
& Statistic & Df & Sig. \\
\hline \multirow{2}{*}{ Pretest } & Eksperimen & 0.921 & 32 & 0.022 \\
& Kontrol & 0.881 & 32 & 0.002 \\
\hline
\end{tabular}

Berdasarkan hasil uji normalitas pada Tabel 4 dapat dilihat bahwa nilai signifikansi (Sig) dari data pretest kemampuan mathematical problem posing daripada kelas eksperimen sebesar 0,022 dan kelas kontrol adalah 0,002. Untuk kelas eksperimen nilai Sig. $(0,022)<0,05$ sehingga $\mathrm{H}_{0}$ ditolak sehingga data tidak berdistribusi normal, begitupun untuk kelas kontrol nilai Sig. $(0,002)<0,05$ sehingga $\mathrm{H}_{0}$ ditolak. Dapat dinyatakan bahwa kedua data pretest tidak berdistribusi normal. Apabila data tidak berdistribusi normal, tidak dilanjutkan uji homogenitas varians. Akan tetapi, dilanjutkan dengan uji non parametrik menggunakan uji Mann-Whitney dengan hipotesis statistik berikut:

$\mathrm{H}_{0}: \mathrm{X}=\mathrm{Y} \quad$ (Tidak terdapat perbedaan kemampuan mathematical problem posing siswa di kelas eksperimen dan kelas kontrol)

$\mathrm{H}_{\mathrm{a}}: \mathrm{X} \neq \mathrm{Y}$ (Terdapat perbedaan kemampuan mathematical problem posing siswa di kelas eksperimen dan kelas kontrol)

Keterangan:

$X$ : Kemampuan mathematical problem posing kelas eksperimen

$\mathrm{Y}$ : Kemampuan mathematical problem posing kelas kontrol

Kriteria pengujian:

Jika nilai Asymp. Sig. > 0,05 maka $\mathrm{H}_{0}$ diterima

Jika nilai Asymp. Sig. $\leq 0,05$ maka $\mathrm{H}_{0}$ ditolak

Hasil uji Mann-Whitney data pretest kemampuan mathematical problem posing kedua kelas disajikan pada Tabel 5 .

Tabel 5. Uji mann-whitney data pretest kemampuan mathematical problem posing

\begin{tabular}{|c|c|c|c|}
\hline \multicolumn{4}{|c|}{ Pretest } \\
\hline Mann-Whitney U & & & 491.000 \\
\hline Wilcoxon W & & & $1,02 E+06$ \\
\hline Z & & & -0.284 \\
\hline Asymp. Sig. (2-tailed) & & & 0.777 \\
\hline \multirow{3}{*}{ Monte Carlo Sig. (2-tailed) } & Sig. & & $0.780^{a}$ \\
\hline & \multirow{2}{*}{$95 \%$ Confidence Interval } & Lower Bound & 0.772 \\
\hline & & Upper Bound & 0.788 \\
\hline \multirow{3}{*}{ Monte Carlo Sig. (1-tailed) } & \multirow{2}{*}{ 95\% Confidence Interval } & Lower Bound & 0.381 \\
\hline & & Upper Bound & 0.401 \\
\hline & Sig. & & $0.391^{a}$ \\
\hline
\end{tabular}

Berdasarkan Tabel 5 diperoleh nilai Asymp. Sig. (2- tailed) sebesar 0,777. Karena nilai Asymp. Sig $(0,777)>0,05$ maka $\mathrm{H}_{0}$ diterima, sehingga dapat disimpulkan bahwa tidak terdapat perbedaan kemampuan mathematical problem posing siswa pada kelas eksperimen dan kelas kontrol. Hal tersebut menunjukkan bahwa kemampuan matematis siswa pada kedua kelas sama.

Selanjutnya, data posttest kemampuan mathematical problem posing siswa dianalisis untuk mengetahui apakah pendekatan open-ended pada kelas eksperimen lebih baik daripada pendekatan 
saintifik pada kelas kontrol. Hasil deskripsi data posttest kemampuan mathematical problem posing ditampilkan pada Tabel 6.

Tabel 6. Deskriptif data posttest kemampuan mathematical problem posing

\begin{tabular}{lcccc}
\hline & Kelas & N & Rata-rata & Std Deviasi \\
\hline \multirow{3}{*}{ Posttest } & Eksperimen & 32 & 35.469 & 2.269 \\
& Kontrol & 32 & 20.281 & 11.871 \\
& SMl & & 50 & \\
\hline
\end{tabular}

Berdasarkan Tabel 6 dapat dilihat bahwa rata-rata posttest kemampuan mathematical problem posing pada kelas eksperimen lebih besar daripada kelas kontrol. Nilai rata-rata posttest dari kedua kelas tersebut menunjukkan bahwa siswa pada kelas eksperimen memiliki kemampuan mathematical problem posing yang lebih baik dibandingkan siswa kelas kontrol. Hal ini pun terlihat dari jawaban siswa kelas eksperimen yang lebih kreatif dalam menyusun masalah dan mengajukan pertanyaan dari informasi yang diperoleh.

Untuk memperoleh signifikansi dari perbedaan dua rata-rata tersebut, dilakukan uji dua perbedaan rata-rata. Tetapi, sebelumnya dilakukan uji normalitas terlebih dahulu untuk mengetahui apakah sampel dari populasi berdistribusi normal atau tidak dengan menggunakan uji statistik Shapiro-Wilk dengan taraf signifikansi 0,05 . Rumusan hipotesisnya sebagai berikut:

$\mathrm{H}_{0}$ : Data posttest berdistribusi normal.

$\mathrm{H}_{\mathrm{a}}$ : Data posttest tidak berdistribusi normal.

Kriteria pengujian yang digunakan adalah:

Jika nilai Sig. $\geq 0,05$ maka data posttest berdistribusi normal.

Jika nilai Sig. <0,05 maka data posttest tidak berdistribusi normal.

Hasil uji normalitas data posttest kelas eksperimen dan kontrol ditampilkan pada Tabel 7.

Tabel 7. Uji normalitas data posttest kemampuan mathematical problem posing

\begin{tabular}{cccc}
\hline Kelas & Statistic & $\begin{array}{c}\text { Shapiro-Wilk } \\
\text { df }\end{array}$ & Sig. \\
\hline Eksperimen & 0.901 & 32 & 0.007 \\
Kontrol & 0.865 & 32 & 0.001 \\
\hline
\end{tabular}

Berdasarkan Tabel 7 dapat dilihat bahwa nilai Sig. (signifikansi) dari uji normalitas data posttest kemampuan mathematical problem posing pada kelas eksperimen adalah 0,007 dan kelas kontrol adalah 0,001. Untuk kelas eksperimen nilai sig $<0,05$ maka $\mathrm{H}_{0}$ ditolak sehingga data posttest tidak berdistribusi normal, begitupun untuk kelas kontrol nilai Sig. $<0,05$ maka $\mathrm{H}_{0}$ ditolak sehingga data tidak berdistribusi normal, maka tidak dilanjutkan uji homogenitas varians. Akan tetapi dilanjutkan dengan uji non parametrik yaitu Mann-Whitney. Adapun hipotesisnya adalah sebagai berikut:

$\mathrm{H}_{0}: \mathrm{X} \leq \mathrm{Y}$ (kemampuan mathematical problem posing yang menggunakan pendekatan open-ended tidak lebih baik daripada yang menggunakan pendekatan saintifik )

$\mathrm{H}_{\mathrm{a}}: \mathrm{X}>\mathrm{Y}$ (kemampuan mathematical problem posing yang menggunakan pendekatan open-ended lebih baik daripada yang menggunakan pendekatan saintifik )

Keterangan:

$X$ : Kemampuan mathematical problem posing siswa kelas eksperimen

$\mathrm{Y}$ : Kemampuan mathematical problem posing siswa kelas kontrol

Hasil uji Mann-Whitney data posttest kemampuan mathematical problem posing dari kedua kelas disajikan pada Tabel 8. 
Tabel 8. Uji mann-whitney data posttest kemampuan mathematical problem posing

\begin{tabular}{|c|c|c|c|}
\hline \multicolumn{4}{|c|}{ Posttest } \\
\hline Mann-Whitney U & & & 338.000 \\
\hline Wilcoxon W & & & 866.000 \\
\hline Z & & & -2.340 \\
\hline Asymp. Sig. (2-tailed) & & & 0.019 \\
\hline \multirow{4}{*}{ Monte Carlo Sig. (2-tailed) } & Sig. & & $0.019 \mathrm{a}$ \\
\hline & & Lower Bound & 0.016 \\
\hline & 95\% Conmuence interval & Upper Bound & 0.021 \\
\hline & $95 \%$ Confidence Interval & Lower Bound & 0.007 \\
\hline \multirow{2}{*}{ Monte Carlo Sig. (1-tailed) } & & Upper Bound & 0.010 \\
\hline & Sig. & & $0.008^{a}$ \\
\hline
\end{tabular}

Berdasarkan Tabel 8 diperoleh monte carlo.Sig (1-tailed) sebesar 0,008, karena asympt.sig $\leq 0,05$ maka $\mathrm{H}_{0}$ ditolak sehingga dapat disimpulkan bahwa kemampuan mathematical problem posing siswa yang menggunakan pendekatan open-ended lebih baik secara signifikan daripada pendekatan saintifik. Adapun berdasarkan data posttest menunjukkan bahwa kemampuan mathematical problem posing siswa SMK yang menggunakan pendekatan open-ended lebih baik daripada siswa yang menggunakan pendekatan saintifik.

Pendekatan open-ended melatih siswa dalam menyusun masalah dan penyelesaian yang bervariasi. Pada pendekatan saintifik, siswa kurang terlatih membuat masalah dan jawaban yang berbeda. Kondisi ini yang membuat pendekatan open-ended lebih baik dalam meningkatkan kemampuan mathematical problem posing siswa. Contoh pertanyaan dan jawaban yang berbeda yang diajukan siswa menggunakan pendekatan open-ended sebagai berikut:

Soal: Akar-akar persamaan kuadrat $x^{2}+x-3=0$ adalah $\alpha$ dan $\beta$. Buatlah lima pertanyaan dari informasi tersebut, kemudian selesaikan!

Pertanyaan dan jawaban ke-1 siswa yang bervariasi dalam mengajukan masalah dan menyelesaikannya melalui pendekatan open-ended disajikan pada Gambar 1.

Jawaban ke-1 siswa: Tentukan nilai $\alpha$ dan $\beta$ yang memenuhi persamaan kuadrat tersebut?

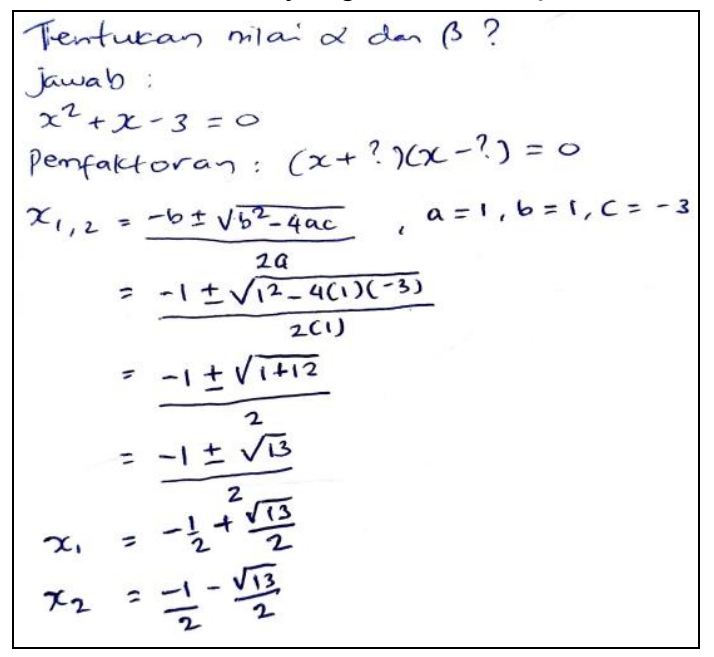

\section{Gambar 1. Pertanyaan dan jawaban ke-1 siswa}

Gambar 1 menunjukkan bahwa siswa mengajukan pertanyaan nilai $\alpha$ dan $\beta$ yang menjadi akar-akar persamaan kuadrat $x^{2}+x-3=0$. Pada awal penyelesaian, siswa mencoba menggunakan konsep pemfaktoran yaitu $(x+\ldots)(x-\ldots)=0$. Siswa tidak dapat memperoleh nilai $\alpha$ dan $\beta$ yang tepat mengisi akar-akar dalam tanda kurung memenuhi persamaan kuadrat. Siswa menyelesaikan 
menggunakan rumus abc yaitu $x_{1,2}=\frac{-b \pm \sqrt{b^{2}-4 a c}}{2 a}$. Berdasarkan rumus tersebut, siswa memperoleh nilai $x_{1}=\frac{-1+\sqrt{13}}{2}=\alpha$ dan $x_{2}=\frac{-1-\sqrt{13}}{2}=\beta$.

Pertanyaan dan jawaban ke-2 siswa yang bervariasi dalam mengajukan masalah dan menyelesaikannya melalui pendekatan open-ended disajikan pada Gambar 2.

Jawaban ke-2 siswa: Tentukan nilai $\alpha+\beta$ ?

$$
\begin{aligned}
& x^{2}+x-3=0 \\
& a=1 \quad \alpha+\beta=\frac{-b}{a}=-\frac{1}{1}=-1 \\
& b=1 \\
& c=-3
\end{aligned}
$$

\section{Gambar 2. Pertanyaan dan jawaban ke-2 siswa}

Gambar 2 menunjukkan jawaban siswa terhadap pertanyaan kedua yang diajukan yaitu menentukan nilai $\alpha+\beta$. Rumus yang digunakan adalah $\alpha+\beta=\frac{-b}{a}$. Berdasarkan rumus tersebut, siswa memperoleh penyelesaian $\alpha+\beta=\frac{-1}{1}=1$.

Pertanyaan dan jawaban ke-3 siswa yang bervariasi dalam mengajukan masalah dan menyelesaikannya melalui pendekatan open-ended disajikan pada Gambar 3. Jawaban ke-3 siswa: Tentukan nilai $\alpha-\beta$ ?

$$
\begin{aligned}
\alpha-\beta \text { ? } & \\
\text { Rumus } \alpha-\beta & =\frac{\sqrt{D}}{a} \\
& =\frac{\sqrt{b^{2}-4 a c}}{a} \\
& =\sqrt{\frac{1^{2}-4 \times 1 \times(-3)}{1}} \\
& =\sqrt{1+12} \\
& =\sqrt{13}
\end{aligned}
$$

\section{Gambar 3. Pertanyaan dan jawaban ke-3 siswa}

Gambar 3 menunjukkan jawaban siswa terhadap pertanyaan ketiga yang diajukan yaitu menentukan nilai $\alpha-\beta$. Rumus yang digunakan adalah $\alpha-\beta=\frac{\sqrt{D}}{a}=\frac{\sqrt{b^{2}-4 \cdot a \cdot c}}{a}$. Berdasarkan rumus tersebut, siswa memperoleh penyelesaian $\alpha-\beta=\frac{\sqrt{1^{2}-4 \cdot 1 \cdot(-3)}}{1}=\sqrt{1+12}=\sqrt{13}$.

Pertanyaan dan jawaban ke-4 siswa yang bervariasi dalam mengajukan masalah dan menyelesaikannya melalui pendekatan open-ended disajikan pada Gambar 4. Jawaban ke-4 siswa: Tentukan $\alpha \cdot \beta$ ?

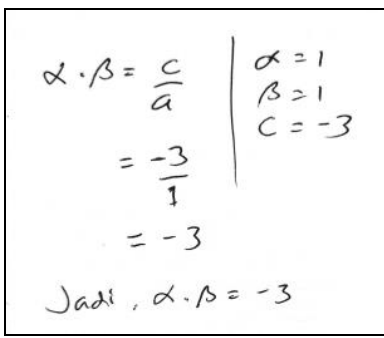

\section{Gambar 4. Pertanyaan dan jawaban ke-4 siswa}


Gambar 4 menunjukkan jawaban siswa terhadap pertanyaan keempat yang diajukan yaitu menentukan nilai $\alpha \cdot \leq \beta$. Rumus yang digunakan adalah $\alpha . \beta=\frac{c}{a}$. Berdasarkan rumus tersebut, siswa memperoleh penyelesaian $\alpha \cdot \beta=\frac{-3}{1}=-3$.

Pertanyaan dan jawaban ke-5 siswa yang bervariasi dalam mengajukan masalah dan menyelesaikannya melalui pendekatan open-ended disajikan pada Gambar 5. Jawaban ke-5 siswa: Tentukan nilai $\frac{\alpha}{\beta}+\frac{\beta}{\alpha}$ ?

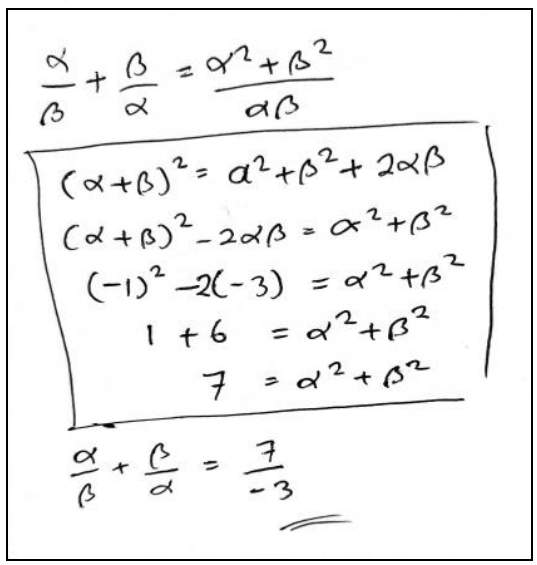

\section{Gambar 5. Pertanyaan dan jawaban ke-5 siswa}

Gambar 5 menunjukkan jawaban siswa terhadap pertanyaan kelima yang diajukan yaitu menentukan nilai $\frac{\alpha}{\beta}+\frac{\beta}{\alpha}$. Rumus yang digunakan adalah $\frac{\alpha}{\beta}+\frac{\beta}{\alpha}=\frac{\alpha^{2}+\beta^{2}}{\alpha \cdot \beta}$. Berdasarkan rumus tersebut, siswa menentukan terlebih dahulu menentukan nilai $\alpha^{2}+\beta^{2}$ melalui penjabaran rumus $(\alpha+\beta)^{2}=\alpha^{2}+\beta^{2}+2 \alpha \beta$ sehingga diperoleh $7=\alpha^{2}+\beta^{2}$. Hasil dari $\frac{\alpha}{\beta}+\frac{\beta}{\alpha}=\frac{7}{-3}$.

Berdasarkan hasil penelitian dan pengolahan data diperoleh bahwa nilai rata-rata posttest dari kedua kelas tersebut menunjukkan bahwa siswa pada kelas eksperimen memiliki kemampuan mathematical problem posing yang lebih baik dibandingkan siswa kelas kontrol. Hal ini pun terlihat dari jawaban siswa kelas eksperimen yang lebih kreatif dalam menyusun masalah dan mengajukan pertanyaan dari informasi yang diperoleh. Penelitian Ardianik et al. (2020) menunjukkan open-ended membuat siswa kreatif dalam menyelesaikan masalah yang ditampilkan dalam bentuk visual dan audio. Hal senada diungkapkan (Zakiah, 2016) bahwa pendekatan open-ended membantu siswa mengeskplorasi materi ke dalam masalah atau pertanyaan-pertanyaan baru. Hal ini dapat membangun kegiatan interaktif antara matematika dengan siswa sehingga siswa terdorong untuk menjawab permasalahan melalui berbagai strategi.

Berdasarkan hasil analisis data posttest kemampuan mathematical problem posing siswa dengan pendekatan open-ended lebih baik dibandingkan dengan pendekatan saintifik. Penelitian Irawan \& Surya (2017) dan Haryani (2020) mengungkapkan pendekatan open-ended meningkatkan kemampuan matematis siswa. Hal tersebut dikarenakan melalui pendekatan open-ended siswa dapat mengeksplor dalam menyusun masalah baru atau membuat pertanyaan berdasarkan informasi yang tersedia sehingga jawaban yang akan mereka gunakanpun bervariasi (Imai, 2000; Kwon et al., 2006).

Subur (2013) mengemukakan bahwa pada awal pembelajaran kreativitas siswa belum terlihat, karena materi prasyarat yang belum sepenuhnya dikuasai sehingga mengakibatkan materi selanjutnya pun terhambat. Namun setelah disampaikannya materi dengan pendekatan open-ended 
pada kelas eksperimen dan pendekatan saintifik pada kelas kontrol kemampuan mathematical problem posing siswapun dapat berkembang.

Penerapan pendekatan open-ended ini melatih kemampuan siswa dalam mengajukan masalah matematis (mathematical problem posing) dan menyelesaikan masalah tersebut. Siswa menjadi terbiasa menyusun pertanyaan-pertanyaan baru dari masalah yang diajukan, sehingga siswa kelas eksperimen yang pembelajarannya menggunakan pendekatan open-ended lebih terlatih kemampuan mathematical problem posing dibandingkan siswa kelas kontrol yang pembelajarannya menggunakan pendekatan saintifik.

Penelitian Kartika (2015) menemukan bahwa kemampuan pengajuan masalah dapat meningkat melalui pembelajaran dengan pendekatan open-ended, ketika siswa mampu mengajukan banyak masalah yang dapat diselesaikan cara yang berbeda. Siswa dapat menemukan cara baru berdasarkan sudut pandang mereka dalam memecahkan masalah maupun mengajukan masalah matematis. Sakti et al. (2017) menyatakan bahwa pendekatan open-ended membuat siswa menjadi lebih kritis dalam menyelesaikan masalah.

\section{KESIMPULAN}

Berdasarkan hasil penelitian data terhadap kemampuan mathematical problem posing siswa SMK dengan menggunakan pendekatan open-ended dan pendekatan saintifik dapat disimpulkan bahwa kemampuan mathematical problem posing siswa SMK yang menggunakan pendekatan open-ended lebih baik daripada yang menggunakan pendekatan saintifik.

\section{REKOMENDASI}

Berdasarkan hasil penelitian, pembelajaran matematika menggunakan pendekatan openended menjadikan siswa lebih mengeksplorasi ide-ide dalam menentukan cara menyelesaikan masalah. Siswa juga terlatih dalam mengajukan pertanyaan dan mereformulasi masalah baru. Pembelajaran open-ended dapat dijadikan alternatif untuk meningkatkan kemampuan mathematical problem posing siswa. Dalam menyusun soal open-ended harus memuat cara penyelesaian yang beragam atau memiliki jawaban yang bervariasi. Soal open-ended harus dirancang dengan optimal agar kemampuan mathematical problem posing siswa dapat berkembang dengan maksimal.

\section{UCAPAN TERIMAKASIH}

Terima kasih kepada pimpinan IKIP Siliwangi yang telah memberikan bantuan dana penelitian melalui hibah internal, Kepala Sekolah SMK TI Pembangunan Cimahi yang telah memberikan izin untuk melakukan penelitian di sekolah, dan siswa kelas XI SMK TI Pembangunan Cimahi yang mendukung terlaksananya kegiatan pembelajaran. Semoga artikel ini bermanfaat bagi penulis khususnya, dan pembaca pada umumnya.

\section{DAFTAR PUSTAKA}

Afriansyah, E. A. (2017). Problem posing sebagai kemampuan matematis. Mosharafa: Jurnal Pendidikan Matematika, 6(1), 163-180.

Afrilianto, M. (2014). Strategi formulate share listen create untuk mengembangkan kemampuan matehamtical problem posing siswa smp. DIDAKTIK: Jurnal IImiah STKIP Siliwangi Bandung, 8(1), 21-28.

Ardianik, Widayat, E., Izzah, N., \& Kusmiyati. (2020). The level of student's creative thinking through solving open ended mathematics from learning style. Systematic Reviews in Pharmacy, 11(9), 207-213. https://doi.org/10.31838/srp.2020.9.34

Erickson, J. A. (2020). Natural language processing for open ended questions in mathematics within 
intelligent tutoring systems. In Proceedings of the 13th International Conference on Educational Data Mining, EDM 2020 (pp. 1-4).

Fatah, A., Suryadi, D., Sabandar, J., \& Turmudi. (2016). Open ended approach: an effort in cultivating students' mathematical creative thinking ability and self esteem in mathematics. Journal On Mathematics Education, 7(1), 11-20.

Haryani, F. (2020). Flexibility in mathematics: case of open-ended graphing task in college algebra. International Journal of Scientific and Technology Research, 9(4), 873-879.

Hosnan. (2016). Pendekatan saintifik dan kontekstual dalam pembelajaran. Bogor: Ghalia Indonesia.

Imai, T. (2000). The influence of overcoming fixation in mathematics towards divergent thinking in open-ended mathematics problems on Japanese junior high school students. International Journal of Mathematical Education in Science and Technology, 31(2), 187-193. https://doi.org/10.1080/002073900287246

Irawan, A., \& Surya, E. (2017). Application of the open ended approach to mathematics learning in the sub-subject of rectangular. International Journal of Sciences : Basic and Applied Research, 33(3), 270-279.

Iskandar, S. M. (2014). Pendekatan keterampilan metakognitif dalam pembelajaran sains di kelas. Erudio Journal of Educational Innovation, 2(2), 13-20. https://doi.org/10.18551/erudio.2-2.3

Kartika, E. (2015). Kreativitas siswa smp rsbi dalam pemecahan dan pengajuan masalah matematika berdasarkan open-ended problem picture ditinjau dari kemampuan matematika. APOTEMA: Jurnal Program Studi Pendidikan Matematika, 1(2), 36-46. https://doi.org/10.31597/ja.v1i2.151

Komalasari, Y., Marlina, N., Ratnapuri, S., \& Amelia, R. (2018). Menganalisis kemampuan mathematical problem possing pada mata pelajaran matematika siswa sma. UNION: Jurnal IImiah Pendidikan Matematika, 6(3), 359-368. https://doi.org/10.30738/union.v6i3.3092

Kwon, O. N., Park, J. S., \& Park, J. H. (2006). Cultivating divergent thinking in mathematics through an open-ended approach. Asia Pacific Education Review, 7(1), 51-61. https://doi.org/10.1007/BF03036784

Melianingsih, N., \& Sugiman, S. (2015). Keefektifan pendekatan open-ended dan problem solving pada pembelajaran bangun ruang sisi datar di smp. Jurnal Riset Pendidikan Matematika, 2(2), 211-223. https://doi.org/10.21831/jrpm.v2i2.7335

Pua, N., Sutarto, \& Yuntawati. (2017). Pengaruh model pembelajaran problem posing terhadap motivasi belajar matematika siswa kelas vii mts $n$ kute lombok tengah tahun pelajaran 2016/2017. In Prosiding Seminar Nasional Pendidik Dan Pengembangan Indonesia (pp. 386390).

Putra, H. D. (2017). Pengembangan instrumen untuk meningkatkan kemampuan mathematical problem posing siswa sma. Euclid, 4(1), 636-645. https://doi.org/10.33603/e.v4i1.211 
Putra, H. D., Herman, T., \& Sumarmo, U. (2017). Development of student worksheets to improve the ability of mathematical problem posing. International Journal on Emerging Mathematics Education, 1(1), 1-10. https://doi.org/10.12928/ijeme.v1i1.5507

Putra, H. D., Herman, T., \& Sumarmo, U. (2020). The impact of scientific approach and what-if-not strategy utilization towards student's mathematical problem posing ability. International Journal of Instruction, 13(1), 669-684. https://doi.org/10.29333/iji.2020.13143a

Sakti, D. P., Hartanto, \& Dharmayana, I. W. (2017). Pengaruh pendekatan open-ended terhadap kemampuan berpikir kritis matematis di sekolah menengah kejuruan. Jurnal Pendidikan Matematika Raflesia, 2(2), 174-182.

Sinambela, P. nauli josip mario. (2013). Kurikulum 2013 dan implementasinya dalam pembelajaran. E-Journal Universitas Negeri Medan, 6, 17-29.

Subur, J. (2013). Analisis kreativitas siswa dalam memecahkan masalah matematika berdasarkan tingkat kemampuan matematika di kelas. Jurnal Penelitian Pendidikan UPI, 13(1), 50-55.

Sudiarta, I. G. P. (2005). Pemngembangan kompetensi berpikir divergen dan kritis melalui pemecahan masalah matematika open ended. Jurnal Pendidikan Dan Pengajaran IKIP Negeri Singaraja, mei, 527-548.

Suherman, E. dkk. (2011). Strategi pembelajaran matematika kontemporer. Bandung: PT Remaja Rosdakarya, 133.

Zakiah, N. E. (2016). Meningkatkan kemampuan metakognitif siswa melalui pembelajaran dengan pendekatan open-ended. Teorema: Teori dan Riset Matematika, 1(1), 27. https://doi.org/10.25157/teorema.v1i1.125 